\section{Big test for bioremediation}

\section{London}

Time, and the action of oil-feeding bacteria, will be the only healers for the Western Gulf coast ecosystem, now threatened by the largest oil slick in history, most marine pollution experts agree. But the slow recovery may be accelerated by the relatively new techniques of bioremediation - adding nutrients or micro-organisms to supplement the natural process of biodegradation.

Oil spills have traditionally been tackled using dispersant chemicals, or by removing the oil physically from beaches and the sea surface. But chemicals must be applied to spilled crude oil quickly, before the volatile components evaporate and

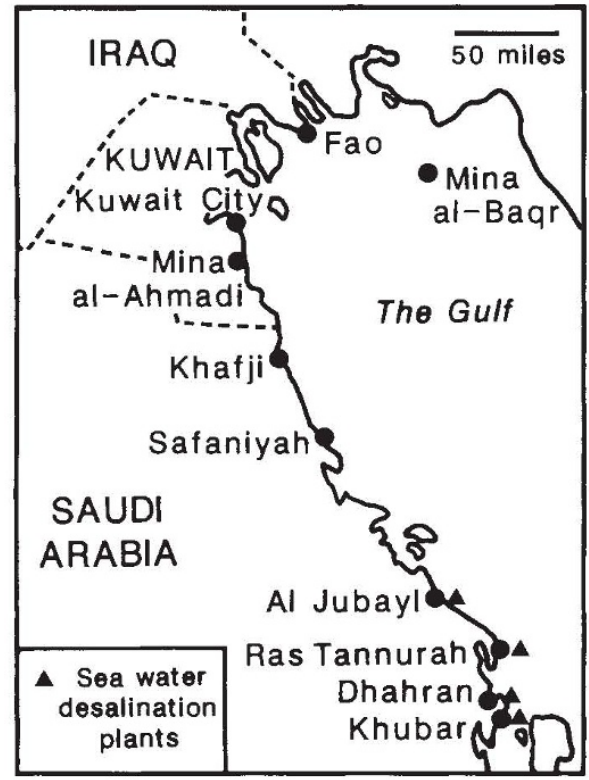

Desalination plants threatened by slick.

the oil weathers to a tar-like consistency. With the main source of the slick (the offshore tanker loading station at Mina alAhmadi in Kuwait, where oil was released by Iraqi forces) in the middle of a war zone, this has proved impossible. Chemical treatment as the oil drifts down the Saudi Arabian coast would in any case be unwise, because dispersed oil droplets would sink, and could then enter the inlet pipes of Saudi desalination plants.

Given the huge volume of oil (probably more than 10 million barrels) and the limited time available, the deployment of oil-containing booms and sea-surfaceskimming equipment will be limited to protecting economically important installations, such as the desalination plants. Richard Golob, publisher of Golob's Oil Pollution Bulletin, says the slick's scale will also make any physical clean-up after the oil comes ashore difficult. More than 10,000 people were drafted in to clean beaches in Prince William Sound, Alaska, after the 1989 Exxon Valdez disaster, where 250,000 barrels were spilt. The new slick "overwhelms the spill-response capability of the Gulf region", Golob says. Left alone, the oil will linger for years.

Bioremediation efforts should be less hampered by the shortage of manpower. Beaches and floating oil can be sprayed periodically, and the bacteria left to carry out their task. But the techniques are relatively new, and nothing has been attempted on this scale before.

After the Valdez spill, Exxon sprayed several hundred kilometres of the Alaskan coastline with fertilizing nutrients, to stimulate the natural populations of bacteria. Oil degraded several times more quickly on these beaches than on untreated sites, says Dick Lessard, Exxon's oil spill technology co-ordinator.

Ron Atlas, from the University of Louisville, believes spraying beaches with nutrients can also help in the Gulf. In theory, the warmer conditions on Gulf beaches will help, if the Valdez techniques are repeated, as the oil-feeding bacteria should be metabolically more active. Despite the larger volume of oil in the Gulf spill, Atlas says that a smaller proportion of the total is likely to reach the shore than in Prince William Sound, which is littered with small islands. Experience with the world's largest previous oil spill, the 3.4 million barrel Ixtoc well blow-out in the Gulf of Mexico in 1979, shows that oil staying offshore poses a smaller ecological threat, Atlas says.

Bioremediation has also been tried on slicks at sea, in the Gulf of Mexico, on a spill from the tanker Mega Borg in June last year. A US Coast Guard vessel sprayed a cocktail of oil- feeding bacteria and fertilizer, together with a biological catalyst. Although the oil disappeared from the treated areas within 16 hours, it is not known whether the treatment, or simply wave action, was responsible. Atlas says there have been no experiments that conclusively prove that bioremediation can work on offshore slicks.

Nevertheless, the Texas company Alpha Environmental, which supplied the bacteria for the Mega Borg clean-up, and its UK sister Alpha Biological Treatment Services are standing by to move two and a half tonnes of their dried bacterial cocktail and 30 oil-drum-sized fermenters to the Gulf. George Hubbard, joint managing director of the UK company, maintains that it will be possible to grow enough bacteria to have a "considerable" impact on the slick, both at sea and on the shore, but adds "it's going to take months". The Alpha cocktail contains some 50 naturally occurring marine bacteria, collected from around the world.

Lessard and Atlas believe it will not be necessary to add new bacteria in the Gulf, along with fertilizer, because previous smaller spills should have nurtured a healthy population of oil-degrading bacteria. But Atlas sees no harm in Alpha's plans, provided that any potentially pathogenic bacteria are kept well away from the desalination plants.

Tony Knights, from the University of Wales at Swansea, who worked on marine pollution in the Gulf in the 1970 s and 1980 s, suggests a low-technology alternative approach to attack the spill while still at sea: the slick could be sprayed with cement powder to bind the oil and make it sink en masse, away from environmentally sensitive areas. But other experts are sceptical of this method. Madeline McDonagh, from the UK Department of Trade and Industry's Warren Spring Laboratory, says sinking the oil will delay its breakdown, and may create problems in the long term, as the oil seeps back to the surface.

Whatever the scope for fighting the existing slick, the biggest fear is that further huge spills are possible, into an almost enclosed sea that averages only 30 metres deep.

Peter Aldhous INDIA

\section{Impact of Gulf War}

\section{New Delhi}

THE Gulf War will have a negligible impact on India's environment and weather according to an assessment by the country's science agencies, but the government has warned of "possible serious long-term adverse effects" on the economy.

Even if the oil slick in the Gulf enters the Arabian Sea, it will not influence the monsoon due to set in on 1 June, says the Department of Science and Technology (DST).

The monsoon depends more on what happens over the Tibetan plateau and the Bay of Bengal than on the Arabian Sea, says Vasant Gowariker, secretary of the department. Conditions in the Arabian Sea are not even included in the model that the DST has used successfully to forecast monsoon behaviour in the past three years. The Arabian Sea is very rough at this time of year and any slick entering it will break up and evaporate leaving tar balls, which Indian coastguard vessels are standing by to scoop up.

A joint study by defence and civilian scientists says pollution caused by fires at oil wells will have no adverse effect on agriculture or the weather but warns that the economy will be hit by damage to Iraqi oil wells -25 per cent of India's oil imports come from Iraq. The government is responding to the threatened energy crisis by enforcing conservation measures, switching to coal wherever possible, and encouraging alternative energy projects such as producing electricity from animal and tidal power. K. S. Jayaraman 